\title{
Chapter 16 \\ From Privatization (of the Expansion Era) \\ to De-privatization (of the Contraction Era): \\ A National Counter-Trend in a Global Context
}

\author{
Marek Kwiek
}

\section{Introduction}

Polish higher education is radically changing: it is still a dual (public-private), highly differentiated, strongly marketized, and greatly expanded system - but under heavy pressures of declining demographics, it is currently becoming more public, less differentiated, less marketized, and greatly contracted. This unexpected change needs scholarly exploration that puts the Polish trend in wider European and global contexts of higher education change. Since 1989, the system has witnessed a phenomenal rise in the number of public and private (not-for-profit) institutions, and the rise (and fall) in the number of students (from 0.40 million in 1989 up to 1.95 million in 2006 and down to 1.55 million in 2013). Private higher education institutions from the very beginning have been almost fully fee-based and profit-driven (although nominally not-for-profit institutions, in fact most of them operated like large-scale for-profit educational companies employing staff predominantly from public institutions). The unprecedented expansion of the system and the stunning growth in its accessibility and affordability have led to an increase in the share of the labor force with higher education credentials to about the Western European average $24 \%$ in 2012). While we have explored the expansion era of 1990-2005 through the concept of "privatization" elsewhere (Kwiek 2010), the system is now contracting (the private sector in particular). This prompts exploration of the ongoing changes through the concept of "de-privatization."

As a concept, "de-privatization" relates to the theory of academic capitalism in important ways. Research in the tradition of academic capitalism (Slaughter and Leslie 1997; Slaughter and Rhoades 2004) explores the ways in which competition for resources - including but not limited to student enrollments - reshapes university

M. Kwiek $(\bowtie)$

University of Poznan, Poznan, Poland

e-mail: kwiekm@amu.edu.pl 
operations. A typical consequence of academic capitalist processes is heightened stratification among universities (Slaughter and Cantwell 2012). In the US, where much research on academic capitalism has been conducted, growing gaps between universities have tended to advantage private universities over their public peers. Relative to their enrollments, private universities tend to enjoy higher status (Cantwell and Taylor 2013) and greater resources (Taylor, Chap. 4 in this volume) than do their public counterparts. Poland therefore provides an important counterexample that adds texture to the academic capitalist account, as suggested by the concept of "de-privatization." Because public subsidies in Poland are attached directly to "seats" rather than to research monies (Rosinger, Taylor, and Slaughter, Chap. 5) or tax advantages (Cantwell, Chap. 9), public universities have improved their position as total enrollment has declined and competition for students has increased. This chapter therefore highlights the ways in which state policies can incent competitions in a manner evocative of the quasi-markets that characterize academic capitalism (Taylor et al. 2013) without necessarily favoring private providers relative to their public counterparts.

The expansion from elite to mass to universal higher education in Poland was abrupt and uncoordinated. At the end of the communist period the gross enrollment rate was about $10 \%$ (1989). Drawing on Martin Trow's terminology, 3 years later, the system entered the age of "massification" (15.5\% in 1992). Within the next 15 years, it moved to the age of "universalization" (51.1\% in 2007 and beyond) (Trow 2010a: 86-142). The enrollment rate grew by a factor of 5 in a decade and a half, occurring in a much shorter period of time than anywhere in Western Europe. Expansion had broad public support from the state, academia, and the public at large. The most important drivers of this change were powerful social pressures to make higher education accessible to ever larger segments of society (Bialecki and Dabrowa-Szefler 2009). These included expansion of the population seeking higher education, a new labor market with growing private sector employment that required a more educated labor force (Baranowska 2011; Kogan et al. 2011), a laissez-faire public policy towards the emergent private sector in higher education (which we have termed "the policy of non-policy," in Kwiek 2008), and the willingness of the academic profession to be very involved in the institutional growth of both public and private sectors (Antonowicz 2012; Kwiek 2012a). The emergence of the private sector in postcommunist countries "took the state and society by surprise. This often meant private proliferation amid little regulation" (Slantcheva and Levy 2007: 5; Scott 2007). Change processes in Poland were typical of Central and Eastern Europe, where countries faced similar challenges stemming from the communist legacy. Post secondary education had to move beyond communist conceptions of universities as organizations that should heavily restrict access, be under strong political supervision and tightly coordinated by the state, as well as engaged in redesigning basic social structures towards a Soviet ideal of social justice.

The combination of demand and supply factors led to unprecedented growth of the Polish system. Public institutions used their newly gained institutional autonomy to offer ever more study programs to ever larger numbers of students, in both previously existing tax-based tracks and in newly emergent fee-based tracks (all 
full-time studies in the public sector are tax-based, e.g., fully subsidized by the state, in accordance with the Polish Constitution, all part-time studies are feebased). The absolute size of the system increased greatly, as did the size and numbers of public and private institutions. The post-1989 period has been a Golden age of Polish higher education with regard to mass, affordable access. ${ }^{1}$ However, expansion came with a notable cost. The national focus on increasing student numbers came at the expense of the research mission of top Polish universities and the relative decline of national academic research output in 1995-2010, especially in "soft" as opposed to "hard" research fields, when compared with the major Central European systems of Hungary, the Czech Republic and the Slovak Republic (Kwiek 2012a).

The expansion era ended about 2006. The contraction era is expected to last for at least another decade for fundamental, demographic reasons (see Fig. 16.1 below).

In contrast to the European Union and the OECD area, ${ }^{2}$ the Polish system is currently both universal (in Trow's terms) and heavily contracting. Consequently, the logics underlying public policy in the postcommunist expansion period (19902005) inevitably differ from the logics underlying it in the contraction period (2006-2025 and beyond). The key parameter of the ongoing change processes is declining demographics, rooted in a huge decline in the birth rate in the early 1990s.

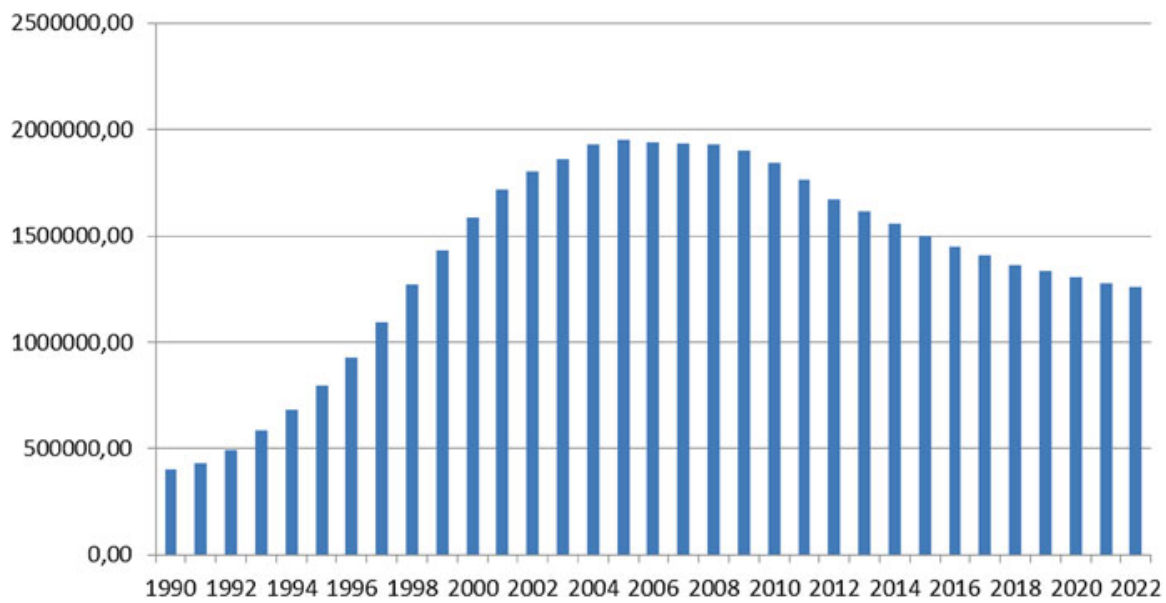

Fig. 16.1 Enrollments in Polish higher education, 1990-2022 (2014-2022 projections) (Source: National statistical data for higher education, main statistical office (1990-2013) and MoSHE (2012) for demographic projections (2014-2022))

\footnotetext{
${ }^{1}$ A recent empirical study based on data from the Polish Household Budget Survey from the 19952008 period shows that improvements in access refer to students with low family educational background living outside large metropolises rather than to students from low-income families, Herbst and Jakub 2014: 14, see Kwiek 2013a for a European comparison of access.

${ }^{2}$ Exceptions are Korea and Japan; see detailed projections in Vincent-Lancrin (2008: 97-103), and analyses in Yonezawa and Kim (2008: 199-220) and Huang (2012).
} 
The population of the 19-24 age group is projected to decrease between 2007 and 2025 by $43 \%$ (GUS 2009) and the number of students is projected to decrease from 1.96 million in 2006 to 1.33 million in 2020 to 1.17 million in 2025 . The private sector enrollment is expected to decrease almost five times, from 660,000 students in 2007 to 151,000 students in 2022 (MoSHE 2012: 7-8). According to several consistent enrolment scenarios based on national statistical data (Vincent-Lancrin 2008: 45; Antonowicz and Godlewski 2011: 10-14; IBE 2011: 110-11; Ernst and Young 2010: 20), enrolments in Poland in 2025 are expected to fall to 55-65 \% of 2005 levels. Thus not only is the expansion era ending, privatization processes prevalent until recently are also in a fundamental retreat, which we explore here in detail.

This paper focuses on what we term "de-privatization" as a local Polish phenomenon, especially with regard to private sector growth and reliance on cost-sharing mechanisms in public sector institutions (Levy 2009; Altbach et al. 2010: 75-84; Johnstone 2012; Johnstone and Marcucci 2010). De-privatizaton may also possibly occur in Central and Eastern European, given declining demographics in Bulgaria, Romania, Slovakia, Estonia, Lithuania and Latvia. De-privatization is a uniquely postcommunist European process today as only in postcommunist Central (and Eastern) Europe has private higher education been on the rise for almost two decades (Kwiek 2013b). Private higher education was stimulated by rapid expansion of access to higher education following the collapse of communism. De-privatization stems from aging populations, marked by dramatically low birth rates since the transition period of the early 1990s. De-privatization is a demographically-driven public-private re-balancing process. Consequently, the current public-private dynamics in postcommunist Europe differ greatly from both Western European and global dynamics. However, Poland may ultimately resemble Western Europe where "normal" has always been predominantly public and free (tax-based) higher education.

\section{Higher Education: From "Privilege" to "Right" to "Obligation". A Brief Historical Context}

Three eras of "massification", "maturation", and "post-massification" in the Polish system (Gumport et al. 1997) were collapsed to about 15 years, in comparison with major industrialized economies where these processes took at least three decades. The unprecedented speed of changes in Poland had unintended policy implications. Consistent with what Martin Trow suggested in the 1970s (2010a), conceptions of participation in higher education changed in Poland in the last three decades from a "privilege" of birth or talent (before 1989) to a "right" for those who had certain formal qualifications (after 1990) to an "obligation" for children from the middle classes (the 2000s and beyond). The new universal yet contracting system leads to entirely new policy dilemmas in both funding and governance, ranging from such issues as how to maintain public and private higher education infrastructure with a shrinking student body to how to differentiate between various institutional types and their functions so that current elite institutions (or their segments) can survive 
in a universal system. Especially interesting are funding dilemmas in the emergent contracted system: should it follow the global (but not Continental European) trends of private sector growth and increasing reliance on cost-sharing mechanisms, or should it increasingly rely on public funding for students in the public sector, treating (the currently shrinking) private sector as a temporary phenomenon of the early postcommunist transition period? In our view, the private sector - currently a "declining industry" (Porter 1980) - was merely a temporary phenomenon. The Polish state allowed private higher education to flourish in the expansion period to cover part of the rising costs of higher education from the private purse. But from the very beginning, as in communist China of the 2000s, "the private higher education sector was designed to be inferior to the public one" (Wang 2014: 110). The two sectors were never equal partners, and the dominance of public institutions in prestige was always taken for granted.

Under communism, access to higher education was heavily restricted: the entry rate for the relevant age cohort in 1990 was $11 \%$. Higher education in Central Europe, as opposed to other industrialized nations, was as elite in 1990 as it was in decades past (Kwiek 2011). The basic trait of Polish higher education, as of the whole economy, in the postwar communist period (1945-1989) was central planning. As Jan Szczepanski (1978: 32) stressed in his 1978 country report on Poland, "since education is an integral part of socioeconomic planning and admission to any institution of higher education is, in principle, a guarantee of employment, the government must try to harmonize admissions with the possibilities for graduate employment." According to the stated needs of the national economy, the numbers of admitted candidates for the whole country were set for every type of institution and for every field of studies. Unsurprisingly, in the majority of fields of study (medicine, architecture, construction, engineering, humanities, teacher training colleges, law schools and economics) between $90 \%$ and $98 \%$ of graduates were employed in the fields in which they graduated. The principle of full employment combined with the principle of carefully planned supply of qualified workers within the closed, national labor market was a key factor limiting the massification of higher education under communism

At the same time, universities in communist countries were used by the government as agents of social change, for example to redress social inequality. This was consistent with the idea that all European communist societies were "political societies" (Szczepanski 1974) in which political aims, ideological values and communist parties' targets were fundamental factors in every public decision. For universities, the target was to implement a change in social stratification by changing the social composition of the educated strata. As Jan Szczepanski (1978: 29) described the doctrine, "the social revolution could be completed only if a strata of intelligentsia were educated from the prerevolutionary lower classes of manual workers and peasants. However, the share of students from lower socioeconomic classes was stable, about $20 \%$, despite the use of a system of "preferential points" among entry criteria, in the 1970s and 1980s." The overall goal of the communist party to have new intelligentsia with roots in working and peasants classes was only partly successful. 
The majority of Polish academics in the second half of the 1970s, and especially in the 1980s, became increasingly indifferent to communist ideals. The whole idea of universities as engines for creating new patterns of social stratification was massively distrusted. In part because academics were indifferent to or unsatisfied with communism, after the transition there were no anticommunist purges in the higher education sector but neither did academics cling to the communist ideology. The most ideologically engaged university departments (e.g. political sciences, economics, and philosophy) changed internally, mostly through hiring young academic staff. The problems after 1990 were not ideological but academic: low research focus combined with marginal research performance and high teaching focus, even in top public universities, combined with academic moonlighting in the private sector. Universities became what we termed internally "divided institutions," with different academic attitudes and behaviors in soft and hard academic disciplines, and declining research production in the former (see Kwiek 2012a, 2014a).

With the fall of communism, private higher education in (some) Central European countries, and in Poland in particular, expanded rapidly. Private sector employment in the market economy grew more slowly. However, as salaries in the new private sector economy grew gradually, ever more young people were pushed into higher education. The demand for degrees was growing and, consistently across the region, the wage premium from higher education for Central European countries was the highest in Europe. Currently the Czech Republic, Hungary, Poland, Slovak Republic, and Slovenia have higher wage premiums for all age brackets than the average for OECD and EU-21 countries (OECD 2013: 111-112). Poland's wage premium is the lowest of the five countries because the Polish labor market is saturated with higher education graduates. The private sector of higher education in Poland was forced to operate "around the periphery of the state system of higher education" (Geiger 1986: 107), because the public sector was also expanding heavily. As Slantcheva and Levy (2007: 1) rightly emphasize, "nowhere else has the change been as concentrated in time and as inclusive of so many countries that share a historical legacy. Although private sector growth has been common worldwide, its development across Central and Eastern Europe is more striking in that it comes against the backdrop of at least four decades of communist public monopoly and historically limited higher education enrollment."

\section{From the Distribution of Growth to the Distribution of Decline}

The fall of communism started massification and universalization processes that were accompanied by increasing hierarchical differentiation of the higher education system. In Poland, as elsewhere in the region, much of the growth was absorbed by public and private second-tier institutions as well as by first-tier public institutions in their academically less demanding and less selective part-time (and fee-based) studies. Fees were relatively low because of competition between a high number of private and public institutions (between 300 and 400 institutions in the 1995-2005 period of most intensive enrolment growth). Outside of Warsaw, tuition at most 
institutions did not exceed 150 USD per month. In 2011, annual average tuition fee for full-time students converted using PPPs was 1242 USD for bachelor programs and 1335 USD for masters programs (OECD 2013: 232). Fee-based participation, which includes all students in the private sector and part-time students in the public sector, was high in the expansion period of 1990-2005, rising from $46.6 \%$ in 1995 to $62.8 \%$ in 2000 and decreasing in 2005 to $58.9 \%$. In the contraction period, it has been systematically decreasing, to $47 \%$ in 2012, and it is expected to decrease to $20 \%$ in 2022 (MoSHE 2012: 8).

Expansion also took place predominantly in specific fields of study, such as social sciences, economics, and law (see Fig. 16.2 below, drawn separately for the public and private sectors). In the private sector, the share of students in these areas was more than $70 \%$ in 2000, and then decreased, but it is still about a half of all enrolments. These fields were especially popular for both demand and supply reasons. On the supply side, they were cheap to teach and did not require any additional infrastructure or investments, and they were the core of the emergent private sector in terms of study fields offered. On the demand side, for students, not surprisingly, they were relatively easy to study and to complete. In the expansion period, credentials were more important than rigorous content. The question "access to what?" was not publicly discussed until the labor market was relatively saturated with graduates in the contraction period, and graduates faced low but steadily increasing unemployment rates. In the current wave of reforms (2009-2012), the field of study-graduate employment link is increasingly important, with obligatory graduate surveys and tracer studies being gradually introduced at institutional and faculty levels (Kwiek 2014a). In some cases only (business and administration, journalism or marketing), the popularity of soft fields was related to their prohibition or nonexistence under communism. Generally, academics from public institu-

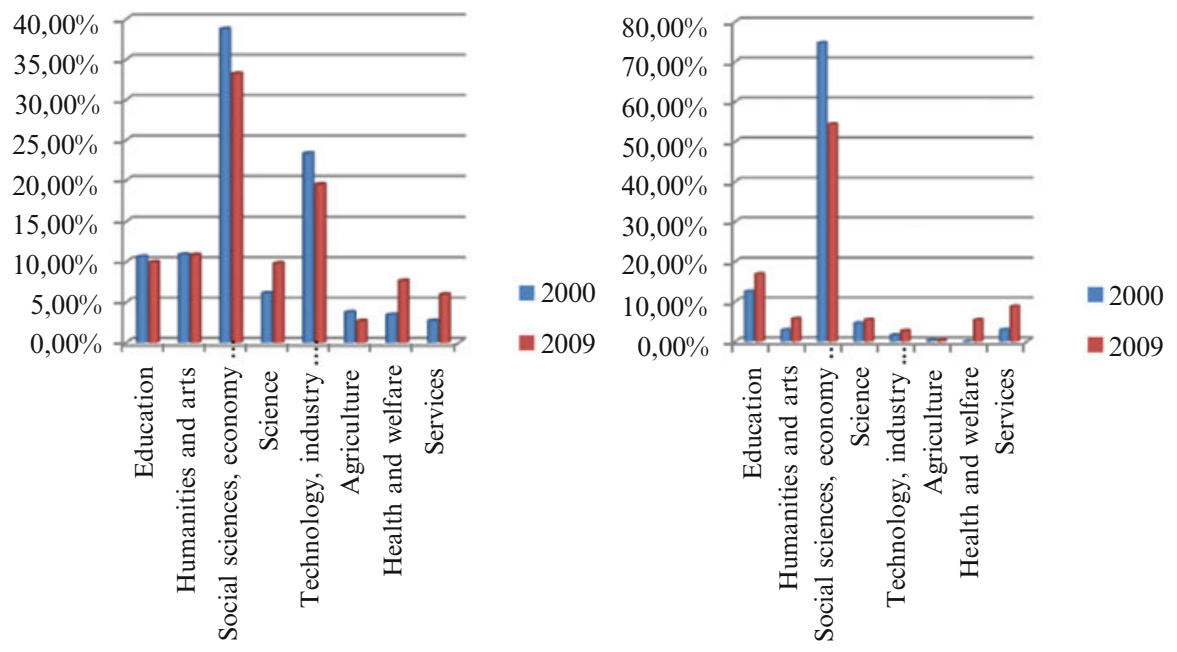

Fig. 16.2 Fields of study: public versus private sectors, 2000 and 2009 
tions in soft fields were heavily involved in fee-based teaching in their institutions and in opening, running, administering and teaching in private sector institutions. There were no transitions of academics to the private sector: only a tiny minority (less than a thousand out of dozens of thousands involved) worked only in the private sector. Consequently, until the early 2010 s, academic "multiple employment" was a major policy issue and a major, massively defended, academic "right." The phenomenon of "travelling professors" was widely known in other postcommunist countries too.

Polish higher education students can be defined by sectors they come from (public and private) and whether they are fee-paying or tax-based students. Fee-paying students are all students from the private sector (both full-time and part-time) and all part-time students from the public sector. Only those (tax-based) full-time students in the public sector do not pay fees - and it is their number which has been increasing in the last few years The increase of full time students in the public sector is one of the elements of a process which we term de-privatization. Currently, $27 \%$ of students are enrolled in private institutions and $73 \%$ in public institution. At the same time, less than half of all students in both sectors, or $47 \%$, paid fees in 2012.

The first impact of the current powerful demographic contraction trend is seen through the stagnating, then falling share of fee-paying students in both sectors (combined) beginning in 2006. Going against the global trend of increasing costsharing (Heller and Callender 2013), the total number of tax-based students increased throughout the last decade. From 2009 to 2012, this figure grew from $44 \%$ to $53 \%$ (GUS 2013: 59). Admission to public higher education is based on scores in national standardized secondary final exams. The selectivity of public institutions is heavily decreasing in the contraction period because they have to select a rising number of students from a falling number of candidates. While the pool of candidates is shrinking year by year, the pool of tax-based places is expanding. Shrinking enrollments mean uncertain academic job prospects. Every public institution, and every department, focuses its strategy on keeping enrollments stable.

The speed of ongoing changes in the student body composition by sources of funding (and by sector) has been amazing. In a zero-sum game, the public sector gains definitely. A good option to compensate for private sector losses is importing international students on a massive scale, which is unlikely as current levels of internationalization are among the lowest in Europe, about 2 \% (or 24,000) in 2012. The future of private higher education in Poland (and the public-private dynamics in the context of a zero-sum game with a relatively fixed pool of Polish applicants and limited inflow of international applicants), is linked to downward demographic trends that are stronger than in any other European Union country.

The tax-based places in metropolitan elite institutions were scarce in the early 1990s and available on rigid meritocratic selection criteria, though the number of tax-based places increased throughout the periods of expansion and contraction. Elite metropolitan universities tried to retain their high quality of teaching during rapid expansion by channelling the newcomers, mostly from the lower socioeconomic classes, to their paid part-time study offers, of considerably lower academic quality than full-time tax-based study. An expanding system needed the 
funds provided by fee-based part-timers. Consequently, entry criteria were very loose: students needed to enrol and pay fees, and there was no or almost no entry selection based on results of standardized tests at the completion of secondary education (Matura exams), or types of secondary education completed. For taxbased full time places, high scores were needed; for fee-based part-time places, just the passing of Matura exams was enough, regardless of the scores achieved. Fulltimers and part-timers never mingled, the former being taught during the week and the latter during weekends.

Students were increasingly seeking credentials to be used in the emergent predominantly private labour market and willing to pay for their education, and public institutions were increasingly seeking additional revenues from part-time students. Elite public universities became open to the newcomers as never before (Wasielewski 2013). The share of students from lower socio-economic classes in tax-based studies reached the $20 \%$ ceiling in the last decade, and in fee-based studies it was higher. In particular, the private sector in higher education (first emergent and then consolidating) was completely open to new clientele, following "open-door" policies. Newcomers to the education sector after 1989 had a choice of going to new regional public universities, fee-based streams in elite metropolitan public universities, or the emergent fee-based private sector. Not surprisingly, Poland smoothly entered the era of universal access to higher education.

But in the current contraction period, masses of poorly qualified newcomers are already able to choose tax-based places in the public sector to an unprecedented extent because the expanded public sector faces declining demographics. The current decline in the number of part-timers seems like a return to normal - but in fact it means channelling of those with lower qualifications to full-time places, previously predominantly taken by those with higher qualifications. The selectivity principle is confronted with the workplace stability principle. If strict selectivity prevails, academic jobs are likely to be lost, which so far is unacceptable regardless of institutional types or fields of study. Thus, first-choice tax-based public places are becoming less selective due to the declining number of candidates and increases in the number of places offered.

\section{Privatization of the Expansion Era, De-privatization of the Contraction Era}

The massification of higher education was inextricably linked to the processes of "external" and "internal" privatization (Kwiek 2010, 2013a). External privatization as we define it means a growth in the number of private higher education institutions and enrollments in this sector. In Poland the number of private institutions grew from 3 (in 1991) to 95 (2000), 315 (2005), and, eventually, 324-328 (circa 2009). Internal privatization means a growing number of fee-based students and growing nominal and/or proportional income from fees in public higher education. In the 
case of Poland, fees are from part-time students enrolled in a nominally tax-based public sector. $^{3}$

We argue that while "privatization" was the key feature of the expansion era (1990-2005), "de-privatization" is becoming the key feature of the contraction era (2006-2025). Or, perhaps we could speak of "re-publicization" of higher education. The gradual decline in the Polish private sector projected for the future is consistent with Daniel C. Levy's (2013) conclusions about the impact of declining demographics on a demand-absorbing type of private sector like that which dominated in Poland:

Much PHE [private higher education] has not had to offer very much, other than access and the prospect or hope of a degree. This helps explain why the demand-absorbing subsector is most vulnerable when demand slows. ... It is the demand-absorbing subsector that is generally the least desired by students. (p. 30)

While Levy sees the potential of private sector decline in public sector growth through what he terms "public university self-privatization" (which clearly intensifies public-private competition), there is another option in contracting systems that he may underestimate: public sector growth without internal privatization. In Poland, public sector growth is combined with de-privatization, that is to say, there are more public sector students enrolled as full-timers (without fees) and fewer public sector students enrolled as part-timers (with fees). In the unique Polish case, there are stable or increasing numbers of tax-based students (and stable or increasing public funding) in the public sector, without explicitly stated (but clear in practical terms) governmental intention to assist the public sector to survive in hard demographic times. While in some countries "internal privatization proves to be a potent way in which the public empire strikes back" (Levy 2013: 38), Poland provides a more traditional response: keeping public funding stable or increasing, which was possible because in the 2008-2013 period Poland has been economically successful. There was no economic recession, and cumulative growth for these years is about $20 \%$. If the public sector continues to grow as projected (without fees), private higher education will be the major loser, becoming what Porter (1980: 254-274) termed a "declining industry" that often "look[s] for optimistic signs since pessimistic ones are so painful." The best strategy for some survivors in the sector may be the identification of a niche or segment with a stable demand.

\footnotetext{
${ }^{3}$ While we are exploring conceptual clarifications about privatization (and de-privatization) elsewhere, let us only indicate that our line of research draws on Daniel C. Levy's studies of the private sector and privatization $(1985,1992)$, Roger L. Geiger's studies on "mass", "parallel" and "peripheral" private sectors and privatization (1986), Gareth Williams' study on "the many faces of privatization" (1996), D. Bruce Johnstone's paper on privatization in and of American higher education (2007) and Simon Marginson' study of "markets in education" (1997). Then useful are papers on privatization and the public/private divide by Arthur Levine (2001), Carlo Salerno (2004) and Simon Marginson (2007), as well as three recent books on privatization across Anglo-Saxon countries: Margaret Thornton's Privatising the Public University. The Case of Law (2012), Douglass M. Priest and Edward P. St. John's Privatization and Public Universities (2006), and Christopher C. Morphew and Peter D. Eckel's Privatizing the Public University (2009).
} 
We view "de-privatization" as a new and suitable concept to study ongoing change processes in higher education (it has not been applied to a higher education context in research literature available in English so far). Processes of higher education change at a national system level in Poland can be defined as stemming from:

- a fully public system under the communist regime (1945-1989), to

- a dual (mixed) public-private system in the massification and expansion period of 1990-2005 (with clear public dominance in terms of share of enrollments and prestige), to

- a de-privatizing system in transition in which the private sector and private funding are playing a decreasing role (2006-2014); and (possibly) to

- a deprivatized system, with a marginal role for the private sector with enrollments slightly above $10 \%$ and the dominant role for the public system and public funding (2025 and beyond).

To sum up: surprisingly, and against powerful global trends in post-massified or universal systems, the Polish dual public-private system is currently re-publicizing. It is increasingly based on public institutions, public research funding, and taxbased students enrolled in the public sector. Thus it is becoming increasingly de-privatized.

Both external and internal privatization in Poland is in a fundamental retreat: the number of private institutions is beginning to fall (from 330 in 2009 to 315 in 2012, and is expected to fall by $80 \%$ within a decades). Enrolments in this sector have been falling continuously, from $34 \%$ in 2007 to $27 \%$ in 2013, and are expected to fall to $12 \%$ by 2022 . The number of fee-based students in the public sector has fallen from $36.2 \%$ in 2007 to $20 \%$ in 2012, and is expected to fall to $8 \%$ by 2022 . In financial terms, the inflow of funding from fees to the system as a whole has also been falling since 2007, and is expected fall farther in the next decade.

The changing share in enrolments over time in the two sectors is U-shaped for the public sector and inverted U-shaped for the private sector, as shown in Fig. 16.3 below. The processes of de-privatization of the system, after a decade and a half of privatization, also means the re-monopolization of the system by the public sector, a return to a standard Western European pattern in which the role of the private sector is marginal as Western Europe is "one of the last hold-outs of free higher education" from a global perspective (Marcucci 2013).

Internal and external dimensions of privatization have their mirror images in the case of de-privatization. Under declining demographics, and in a heavily contracting system, "external de-privatization" of Polish higher education, or the gradual disappearance of private higher education institutions and their systematically falling enrollments in a contraction period, is a mirror image of "external privatization," or the gradual emergence of private higher education institutions and their systematically increasing enrollments in an expansion period. To a degree, external privatization can be viewed as a protection measure for public sector institutions in tough demographic times. Public institutions are able to accommodate to new demographic realities (in a zero-sum game of the falling total number of students in both sectors) because the state continues to be willing to provide tax-based higher education. And 


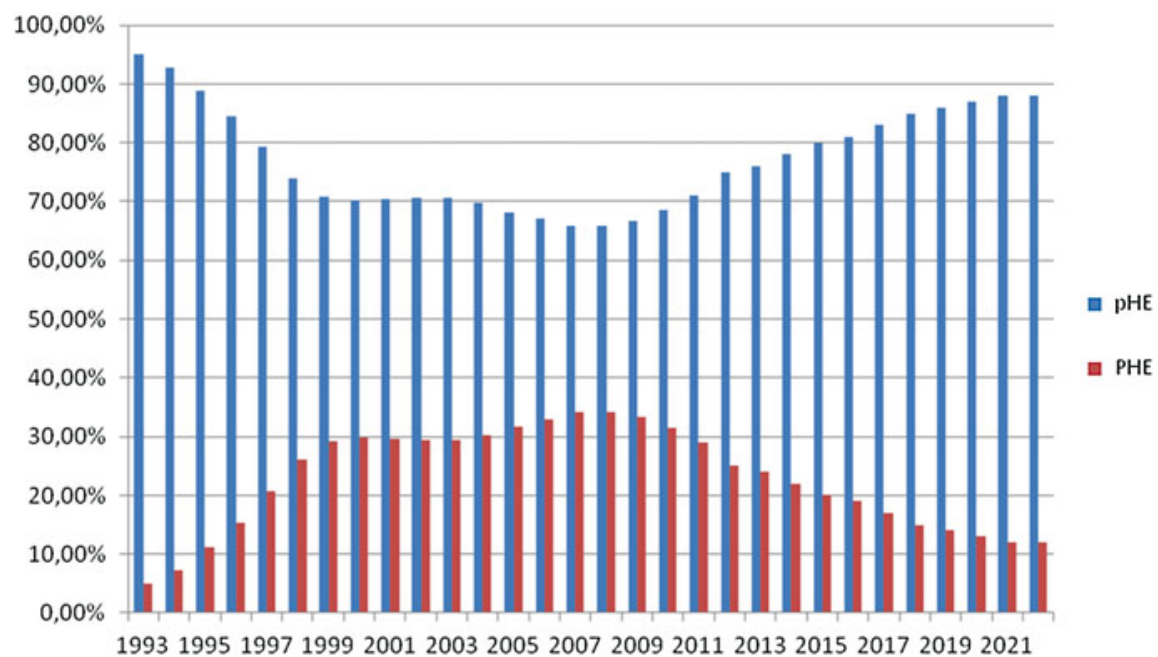

Fig. 16.3 Change in the share of enrollments, by sectors (pHE - public, PHE - private), in percent (2013-2022 projections)

"internal de-privatization" of Polish higher education, or gradually decreasing income from fees charged only to part-time students in a contraction period, is a mirror image of "internal privatization," or increasing income from fees in an expansion period. "Internal de-privatization" occurs because those previously paying fees for part-time studies now find access to tax-based full-time studies.

And de-privatization can be seen as a gradual return of public institutions to a predominantly public funding environment. Ever fewer numbers of fee-based students mean an ever smaller share of fees in public institutions' total operating budgets, as testified by annual financial statements of top ten public universities from 2007 to 2013. During those years, income from fees declined systematically even in the two most prestigious universities, University of Warsaw and Jagiellonian University of Cracow.

The abruptness of changes in the public/private dynamics theoretically might be mitigated by the introduction of universal fees in the public sector, on the assumption that decreasing the fee gap between tax-based public universities and fee-based private universities would shift some enrollments into privates. Theoretically, in Levy's (1986) typology of public/private mixes in funding regimes, the system could move gradually from a "dual and distinctive" ideal typical model to a "dual and homogenized" ideal typical model in which both sectors are funded through a combination of universal fees and direct public subsidies. As Levy (2013: 16) emphasizes in his recent seminal paper on the decline of private higher education, "a general increase in tuition at public universities can lead to loss of public market share, as it decreases the 'tuition gap' between public and private institutions," making private institutions more attractive. However, in Poland, with no fees in the 
public sector, the tuition gap is maximal. And Poland has a long-established tradition of higher education being funded almost exclusively from the public purse.

However, this mitigating policy option seems rather unrealistic. The standard cost-sharing arguments tend to assume that total higher education costs are rising; the burden for these costs must be distributed, so the argument goes (see especially Johnstone 2007; Johnstone and Marcucci 2010). Such analyses are less convincing in contracting systems because public expenditures on higher education are expected fall rather than increase due to demographic changes noted above.

In general terms, the two global privatization agendas of cost-sharing and private sector growth are not expected to be translated into national policy changes in Poland, especially in a current European Union context in which neither agenda is strong. In principle, the universalization of higher education directly invites both agendas, given that that they tend to reduce public funding for social and public sector services. However, a European Union context (except for England with high deferred tuition fees) still matters, and substantially mitigates their local influence in Poland. As Callender and Heller (2013: 254) put it explicitly, "underpinning this global cost-sharing trend are gradual transformations in beliefs about higher education, its role in society, who should provide higher education, who benefits, and so therefore who should pay." However, beliefs take time to become rooted and transformed. Despite almost a quarter of a century of private sector and fee-based tracks in the public sector in Poland, these access-increasing instruments - which clearly absorbed social demand in the expansion period - are still viewed with suspicion by both the labor market and the public at large. As the subtitle of a collection of essays on private education in postcommunist Europe indicates, private sector institutions are still "in search of legitimacy" (Slantcheva and Levy 2007) because their "shocking newness and deviation from established norms naturally make legitimacy problematic" (Slantcheva and Levy 2007: 281). Contrary to elite roles assumed by prestigious private universities in the USA, the private sector in the region took up overwhelmingly demand-absorbing roles, with only a limited number of institutions aspiring to semi-elite status (Levy 2011). From the very beginning, as in most European systems (with only several exceptions such as, for instance, les grandes écoles in France), it was clear that prestige is located only where research is performed. In Poland, as elsewhere in the region, research is located in the top public institutions (Kwiek 2014a, Kwiek 2012b).

\section{Increasing Competition: Towards Higher Intra-Sectoral Differentiation and Inter-Sectoral Public-Private Homogenization}

The massification (high and rising enrollment rates) and expansion (rising student numbers) period of 1990-1995 was accompanied by institutional cooperation rather than competition, both in intra-sectoral (public-public and private-private) and 
inter-sectoral (public-private) terms. In contrast, the current universalization (high and stable enrollment rates) and contraction (declining student numbers) period is increasingly accompanied by competition, both intra-sectorally and inter-sectorally. The big and increasing pool of prospective students from the past two decades is shrinking. As of October 2013, regulations no longer allow multiple site employment for public-sector academic faculty after 2 years of the vacatio legis period, and all senior academics are ascribed to the so called "staff minimum" of a given (public or private) institution. Moonlighting in the private sector is still possible but only on a per hour basis. Two decades of moonlighting had detrimental effects on academic norms and behaviors, and contributed strongly to low research productivity. Fortythree percent of Polish academics in the university sector do not publish at all (Kwiek 2014c). Now things seem to be coming back to normal: one professor, one institution, one full-time job. Hopefully, under current reforms Poland, currently the lowest in publishing among the 11 European countries studied, will gradually increase its share of publishers in top public universities, strengthening faculty research orientation.

A likely response to shrinking financial resources available to the system as a whole is the increased competition for students between institutions of both sectors and among institutions within each sector. Increased competition for students and the financial resources they bring through fees or public subsidies might potentially increase differentiation. In the Polish case, though, the likely outcome may be intersectoral public/private homogenization. In other words, all institutions may be increasingly client-seeking, that is, looking for students in a shrinking national pool of candidates. The system may be returning to the status quo in which public institutions are in a near-monopolistic position, forced to differ more in their educational offerings than ever before. Private institutions may be heavily reduced in numbers and in both enrolment share (12\% expected in 2022) and student numbers (about 150,000 expected in 2022, as in current Ministerial projections). The gradual decline of one sector is thus inevitably leading to the hegemony of the other sector. In all probability, tertium non datur (although the history of higher education research tends to show that it should strongly avoid large-scale predictions).

The changing public-private dynamics take different forms in different clusters of systems in Europe. For instance, in the Nordic context, higher education systems are predominantly public. Wherever private institutions appear, as in Norway and Sweden, they are still publicly-funded despite their private legal status. In contrast, Central Europe, including Poland, is one of the European regions where private means "independent private," defined by OECD as obtaining more than $50 \%$ of income from fees. At such universities, staff are not employed by the state

The decline of private higher education is a rare theme in scholarly literature, as it is a rare phenomenon from a global perspective. But it is also rare for universal higher education systems to be contracting. As Levy stresses,

Many types of private higher education do decline and for various reasons. Yet, private higher education grows significantly despite all the negative factors identified. The overall private higher education decrease almost always refers to public- and private-sectors shares, not absolute enrollments. Even proportional decline in the private sector applies only to a minority of countries. (Levy 2010: 11) 
Poland, together with several other postcommunist European countries, is therefore currently exceptional from a global perspective: both private shares in enrollments and also private absolute enrollments have been systematically decreasing in the last 7 years. The 315 private higher education institutions will compete for shrinking numbers of students. The demographic shift in Poland also creates a major institutional funding challenge to the public and introduces fierce competition among universities, but for private institutions, it may be a life or death challenge. A dream of the public-private competition (and public-private "markets" or "quasimarkets") may have ended, but the competition for top students through new course offerings will still be in place. The public sector will likely be stratified, with a few prestigious, highly ranked institutions at the top, and the remaining, mostly opendoor institutions below. The stratification processes are well advanced today, accelerated by ever more competitive public research funding streams, concentrated in top 20 public institutions. In those institutions at the top of the academic pyramid, fluctuations in student numbers will matter less than the steady attraction of research Euros.

\section{Conclusions and Policy Implications}

Two major global trends in higher education funding and governance seem to affect only some parts of Europe: the increasing reliance of cost-sharing mechanisms in the public sector and the growth of the privates, or what we term here "internal" and "external" privatization of higher education. The two Polish trends of "internal" and "external" "de-privatization" (decreasing fee-based private funding in public institutions, and decreasing share of enrollments and student numbers in private institutions, combined with their shrinking numbers, mergers, and closures) are rare both globally and in the European Union. The long-term, systematic contraction of Polish higher education may precede by a decade similar demographic trends in other European countries such as Germany and Spain (Vincent-Lancrin 2008: 49-51). However, de-privatization processes will likely not occur there because there is no private sector and public funding for higher education is already gradually decreasing rather than increasing. The fall in enrolment levels in Poland is projected to be one of the highest in Europe, and comparable only with other postcommunist countries such as Bulgaria, Romania, Slovakia, Estonia, Lithuania and Latvia. De-privatization is a postcommunist European phenomenon today as only in postcommunist Central (and Eastern) Europe was private higher education on the rise for almost two decades.

Clearly in Poland, there is more public funding for higher education, both nominally and proportionally, compared with private funding. This is true both in teaching and research. There is an increasing share of students in the public sector, and a decreasing share in the private sector The public sector also has an increasing share of tax-based students and a decreasing share of fee-based students. The cost-sharing agenda is weak, and public and academic arguments for the introduction of universal fees (across both public and private sectors) are weaker than ever before. 
From a historical perspective, what we may term "the privatization experiment" in higher education in Poland may be interpreted as merely a transitional phenomenon. Within a massification/maturation/post-massification cycle, it can be viewed as a highly useful experiment during accelerated massification, a less useful experiment during maturation, and, finally, an experiment of marginal usefulness in a post-massified period.

The Polish case study is important for several reasons: public-private dynamics are rapidly changing in a system that has the highest enrolments in the private sector in the European Union. In the global context of expanding higher education systems, there are several systems in Central and Eastern Europe, and Poland is the biggest of them, that are actually contracting. Their contraction is fundamental and rooted in systematically declining demographics. In the global (rather than European) context of increasing reliance on cost-sharing mechanisms in university funding, and on the private sector paradigm in university governance, the Polish system seems to be moving in the opposite direction. Global trends towards higher education privatization can be juxtaposed with the Polish counter-trend towards higher education de-privatization.

This paper is an exercise in locating national trends in higher education funding and governance in wider global and European contexts to see to what extent various "convergence" themes fit a national case. Clearly, postcommunist systems in Central and Eastern Europe might follow a different trajectory in the coming decade and to a traditional catalogue of historical, political and economic differentiating factors, we should add one more, namely different demographics, which are routinely underestimated in higher education research. ${ }^{4}$

Acknowledgements The author gratefully acknowledges the support of the National Research Council (NCN) through its MAESTRO grant DEC-2011/02/A/HS6/00183 (2012-2017).

\section{References}

Altbach, P. G., Reisberg, L., \& Rumbley, L. E. (2010). Trends in global higher education: Tracking an academic revolution. Paris: UNESCO Publishing.

Antonowicz, D. (2012). External influences and local responses. Changes in Polish higher education 1990-2005. In M. Kwiek \& P. Maassen (Eds.), National higher education reforms in a European context: Comparative reflections on Poland and Norway. Frankfurt/New York: Peter Lang.

\footnotetext{
${ }^{4}$ I would like to express my gratitude to Sheila Slaughter and Barrett Taylor for their encouragement to write this paper and thoughtful comments on its first version. I would also like to thank Simon Marginson and Anna Smolentseva (as well as participants in a seminar on "High Participation Systems" organized in September 2013 in Higher Schools of Economics, Moscow) for their invitation to write a first conceptual approach to this paper and for their stimulating comments. My thinking about the public-private dynamics in higher education have also been heavily influenced by a decade of collaboration and exchanges with Daniel C. Levy, for which I am very grateful. All traditional disclaimers certainly apply.
} 
Antonowicz, D., \& Godlewski, B. (2011). Demograficzne tsunami. Raport Instytutu Sokratesa na temat wpływu zmian demograficznych na szkolnictwo wyższe do 2020 roku. Warsaw: Instytut Sokratesa.

Baranowska, A. (2011). Does horizontal differentiation make any difference? Heterogeneity of educational degrees and labor market entry in Poland. In I. Kogan, C. Noelke, \& M. Gebel (Eds.), Making the transition: Education and labor market entry in Central and Eastern Europe (pp. 216-239). Stanford: Stanford University Press.

Bialecki, I., \& Dabrowa-Szefler, M. (2009). Polish higher education in transition. Between policy making and autonomy. In D. Palfreyman \& D. T. Tapper (Eds.), Structuring mass higher education. The role of elite institutions (pp. 183-199). London: Routledge.

Cantwell, B., \& Taylor, B. J. (2013). Global status, inter-institutional stratification, and organizational segmentation: A time-dynamic tobit analysis of ARWU position among US Universities. Minerva, 51(2), 195-223.

Ernst and Young. (2010). Strategia rozwoju szkolnictwa wyzszego w Polsce do 2020 roku. Warsaw: Ernst and Young.

Geiger, R. L. (1986). Private sectors in higher education. Structure, function, and change in eight countries. Ann Arbor: The University of Michigan Press.

Geiger, R. L. (1988). Conference report: Privatization of higher education. Princeton: International Council for Educational Development.

Goedegebuure, L., Lynn Meek, V., Kivinen, O., \& Rinne, R. (1996). On diversity, differentiation and convergence. In V. Lynn Meek, L. Goedegebuure, O. Kivinen, \& R. Rinne (Eds.), The mockers and mocked: Comparative perspectives on differentiation, convergence and diversity in higher education (pp. 2-13). Bingley: Emerald Group Publishing.

Gumport, P. J., Iannozzi, M., Shaman, S., \& Zemsky, R. (1997). The United States country report: Trends in higher education from massification to post-massification. In Academic reforms in the world: Situation and perspective in the massification stage of higher education (RIHE international seminar reports no. 10, pp. 57-93). Rihe: Hiroshima University.

GUS. (2009). Population projection for Poland 2008-2035. Warsaw: GUS (Central Statistical Office).

GUS. (2013). Higher education institutions and their finances in 2012. Warsaw: GUS (Central Statistical Office).

Heller, D. E., \& Callender, C. (Eds.). (2013). Student financing of higher education. A comparative perspective. New York: Routledge.

Herbst, M., \& Rok, J. (2014). Equity in an educational boom: Lessons from the expansion and marketisation of tertiary schooling in Poland. European Journal of Education, 49(3), 435-450.

Huang, F. (2012). Higher education from massification to universal access: A perspective from Japan. Higher Education, 63, 257-270.

IBE. (2011). Spoleczenstwo w drodze do wiedzy. Raport o stanie edukacji 2010. Warsaw: Instytut Badan Edukacyjnych.

Johnstone, D. B. (2007). Privatization in and of higher education. Paper presented at the international comparative higher education finance and accessibility project. Available from www.gse. buffalo.edu

Johnstone, D. B. (2012). The costs of higher education. In P. G. Altbach (Ed.), International higher education. An encyclopedia: Volume 1 (pp. 59-89). New York/London: Garland Publishing.

Johnstone, D. B., \& Marcucci, P. (2010). Financing higher education worldwide. Who pays? Who should pay? Baltimore: The Johns Hopkins University Press.

Kogan, I., Noelke, C., \& Gebel, M. (Eds.). (2011). Making the transition: Education and labor market entry in Central and Eastern Europe. Stanford: Stanford University Press.

Kwiek, M. (2008). Accessibility and equity, market forces and entrepreneurship: Developments in higher education in Central and Eastern Europe. Higher Education Management and Policy, 20(1), 89-110.

Kwiek, M. (2010). Creeping marketization: Where polish private and public higher education sectors meet. In R. Brown (Ed.), Higher education and the market (pp. 135-146). New York: Routledge. 
Kwiek, M. (2011). Universities and knowledge production in Central Europe. In P. Temple (Ed.), Universities in the knowledge economy. Higher education organisation and global change. New York: Routledge.

Kwiek, M. (2012a). Changing higher education policies: From the deinstitutionalization to the reinstitutionalization of the research mission in polish universities. Science and Public Policy, $39,641-654$.

Kwiek, M. (2012b). Universities, regional development and economic competitiveness: The polish case. In R. Pinheiro, P. Benneworth, \& G. A. Jones (Eds.), Universities and regional development. A critical assessment of tensions and contradictions (pp. 69-85). New York: Routledge.

Kwiek, M. (2013a). Knowledge production in European Universities. States, markets, and academic entrepreneurialism. Frankfurt/New York: Peter Lang.

Kwiek, M. (2013b). From system expansion to system contraction: Access to higher education in Poland. Comparative Education Review, 57(3 (Fall)), 553-576.

Kwiek, M. (2014a). Structural changes in the polish higher education system (1990-2010): A synthetic view. European Journal of Higher Education, 4(3), 266-280.

Kwiek, M. (2014b). Changing higher education and welfare states in postcommunist Central Europe: New contexts leading to new typologies? Human Affairs, 24(1), 48-87.

Kwiek, M. (2014c). The internationalization of the Polish academic profession. A European comparative approach. Zeitschrift für Pädagogik, 60(5), 681-695.

Levine, A. (2001). Privatization in higher education. Available from: www.nga.org

Levy, D. C. (1986). 'Private' and 'Public': Analysis amid ambiguity in higher education. In D. C. Levy (Ed.), Private education. Studies in choice and public policy. Oxford: Oxford University Press.

Levy, D. C. (1992). Private institutions of higher education. In B. R. Clark \& G. Neave (Eds.), The encyclopedia of higher education (Vol. 2, pp. 1183-1194). Oxford: Pergamon Press.

Levy, D. C. (2009). Growth and typology. In S. Bjarnason et al. (Eds.), A new dynamic: Private higher education. Paris: UNESCO.

Levy, D. C. (2011). Public policy for private higher education: A global analysis. Journal of Comparative Policy Analysis, 13(4), 383-396.

Levy, D. C. (2013). The decline of private higher education. Higher Education Policy, 26, 25-42.

Marcucci, P. (2013). The politics of student funding policies from a comparative perspective. In D. E. Heller \& C. Callender (Eds.), Student financing of higher education. A comparative perspective (pp. 9-31). New York: Routledge.

Marginson, S. (1997). Markets in education. St Leonards: Allen \& Unwin.

Marginson, S. (2007). The public/private divide in higher education: A global revision. Higher Education, 53, 307-333.

Morphew, C. C., \& Eckel, P. D. (Eds.). (2009). Privatizing the public university. Perspectives from across the academy. Baltimore: The Johns Hopkins University Press.

MoSHE. (2012). Projekt zalozen projektu ustawy o zmianie ustawy - Prawo o szkolnictwie wyzszym oraz niektorych innych ustaw. Warsaw: Ministry of Science and Higher Education (mimeo).

OECD. (2013). Education at a Glance 2013. OECD Indicatora. Paris: OECD.

Porter, M. E. (1980). Competitive strategy. Techniques for analyzing industries and competitors. New York: Free Press.

Priest, D. M., \& St John, E. P. (Eds.). (2006). Privatization and public universities. Bloomington: Indiana University Press.

Salerno, C. (2004). Public money and private providers: Funding channels and national patterns in four countries. Higher Education, 48, 101-130.

Scott, P. (2007). Reflections on private higher education tendencies in Central and Eastern Europe. In S. Slantcheva \& D. C. Levy (Eds.), Private higher education in post-communist Europe. In search of legitimacy (pp. 299-316). New York: Palgrave.

Slantcheva, S., \& Levy, D. C. (2007). Private higher education in post-communist Europe: In search of legitimacy. In S. Slantcheva \& D. C. Levy (Eds.), Private higher education in postcommunist Europe. In search of legitimacy (pp. 1-23). New York: Palgrave. 
Slaughter, S., \& Cantwell, B. (2012). Transatlantic moves to the market. Higher Education, 63(5), 583-606.

Slaughter, S., \& Leslie, L. L. (1997). Academic capitalism. Baltimore: The Johns Hopkins University Press.

Slaughter, S., \& Rhoades, G. (2004). Academic capitalism and the new economy. Baltimore: The Johns Hopkins University Press.

Szczepanski, J. (1974). Higher education in Eastern Europe. New York: International Council for Educational Development.

Szczepanski, J. (1978). Systems of higher education: Poland. New York: International Council of Educational Development.

Taylor, B. J., Cantwell, B., \& Slaughter, S. (2013). Quasi-markets in US higher education: Humanities emphasis and institutional revenues. Journal of Higher Education, 84(5), 675-707.

Thornton, M. (2012). Privatising the public university. The case of law. New York: Routledge.

Trow, M. (2010). Problems in transition from elite to mass higher education. In M. Burrage (Ed.), Twentieth-century higher education. Elite to mass to universal (pp. 86-142). Baltimore: Johns Hopkins University Press.

Vincent-Lancrin, S. (2008). What is the impact of demography on higher education systems? A forward-looking approach for OECD countries. In Organisation for Economic Co-operation and Development (Ed.), Higher education to 2030. Volume 1: Demography (pp. 41-104). Paris: OECD.

Wang, L. (2014). The road to privatization of higher education in China. A new cultural revolution? Dordrecht: Springer.

Wasielewski, K. (2013). Mlodziez wiejska na uniwersytecie - droga na studia, mechanizmy alokacji, postawy wobec studiow. Torun: UMK.

Williams, G. (1996). The many faces of privatization. Higher Education Management, 8(3), $39-56$.

Yonezawa, A., \& Kim, T. (2008). The future of higher education in the context of a shrinking students population: Policy challenges for Japan and Korea. In Organisation for Economic Co-operation and Development (Ed.), OECD, higher education to 2030. Volume 1. Demography (pp. 199-220). Paris: OECD. 